\title{
Challenges teachers face when teaching ELL students in a private school in Mount Lebanon
}

\author{
Samar Zeitoun \\ Lebanese University, Faculty of Education \\ Helenelabed \\ Lebanese University, Faculty of Education
}

\begin{abstract}
The purpose of this study was to measure the impact of an intervention program on ELLs (English language learners), coming from diverse backgrounds with a non-English or limited English language> The study was carried out in a K-12 private school in Mount Lebanon. The sample was comprised of 3 EIP (English Intensive program) teachers, 2 ELLs of different upper elementary levels ( 5 \& 6), and English supervisor or coordinator, EIP supervisor (the researcher), and the head of elementary 2 nd cycle division. The research methodology employed action research-multi case study, and data was collected via 3 tools pre and post the intervention through a mixed method qualitative and quantitative design. These were: (1) Classroom Data Collection tools within 2 types of tools that are observation tools pre and post implementation of workshops done to check the success of implementing new strategies with ELLs, and content analysis tool for students' writing samples, pre and post implementation, to check the impact of the intervention program on enhancing their writing skills ;(2) Questionnaires: English Teachers' Questionnaire for needs analysis, EIP teachers' questionnaire to check the impact of the intervention program on teachers as a post implementation tool, and students' questionnaire post implementation to check the impact of the intervention program on students; (3)Teachers' interview pre implementation to measure supervisor's practices, difficulties ELLs face, and teachers' challenges in teaching ELLs, and to take further suggestions. Also, a post implementation interview was conducted to check effective strategies used to enhance writing skills of ELLs. Descriptive statistics and content analysis were used to analyze respectively qualitative and qualitative data. Results also pinpoints important activities that match unique ELLs' needs and enhance their writing skills. The study ended by recommendations for educational supervisors and teachers
\end{abstract}

\section{INTRODUCTION}

Quality education is a desired goal of all schools and societies. The worldwide demand for good communication skills in English has created a great need for quality language teaching with the best resources, material, and instruction around the world. The process of learning English as a second language has changed in the last thirty years. Earlier, there was a primarily focus on the mastery of grammatical competence, and memorization of certain dialogues; later, a movement towards activities, role plays, and group work took place to enhance creativity and critical thinking. Also, technology including media with its entire means has given everyone the access to learn about almost everything as Moreno (2005) has explained. However, students face many difficulties in learning a foreign language in general and English as a second language in particular. Teaching English as a second language is very challenging for teachers too because students have different abilities and learn at different pace.

Although the Lebanese curriculum encourages the development of various intervention programs that satisfy the needs of different learners (MEHE, 2011), yet not all Lebanese schools cater for additional programs. However, such programs are really important in giving 
equal chances of learning for different students as mentioned in the Lebanese law statements $(105,108,110)$ "Education available on the basis of equal opportunity" (CRC/C/129/Add.7, 25 October 2005). In general, many strategies are applied in the Lebanese context such as "Assessment of teacher English skills" carried out by D-rasati project to ensure that the Ministry had current and reliable data around which to build language-specific training plans for public school teachers. Also The Progress Scale classroom observation tool was developed to assess the quality of classroom instructional practice along a number of dimensions that align with the standards for performance for Lebanese teachers and characterize best practices currently emphasized in educational reform documents across the globe. Results of 2015 OECD's PISA (Program for International Student Assessment) survey in Asian countries, which tested more than 510,000 students in 65 countries and economies on Math, Reading, and Science, indicated that the gender gap in reading performance- favoring girls - widened in eleven countries and economies. Lebanese students' performance in English is relatively low compared to international student assessment result. With an average of 347, Lebanon was classified among the countries/ economies with a mean performance below the OECD average (OECD, 2015).

Improving English language proficiency in Lebanon is a distant, though not unattainable national goal. Language proficiency, at the end of the Intermediate Cycle, is related to diverse factors affecting examination outcomes, ranging from the national situation (regional differences, the national political climate and political influences), to factors relating to the educational situation and teacher status (including the education system, financial resources, physical resources, school programs, teaching materials, teacher training, staff mobility and personal attributes); and student related factors (social and economic status, language exposure and continuity and consistency in the learning process) (Gaith \& Awada, 2014). Researchers argue that considering Lebanese Brevet official exams as a passing grade is unreliable, due to various influencing factors, including governmental changes, innovative planning strategies and technological applications (Khodor, n.d). However, effective change through new policies has already made an impact through the MEHE and the CERD to combat English learning problems in Lebanese public schools (Awada \& Diab, 2016). Continued cooperative and consistent planning should bear the fruit of these efforts in bringing us closer to English language proficiency as a means of inter-cultural communication, co-existence in a global country, and the means to explore and express our individual cultural values and skills (Basha \& Bahous, 2011).

Classroom teachers have very limited professional development to help them effectively teach their grade-level content to limited English proficient students. However, for teachers and supervisors to be as effective as possible, it is crucial that they expand their skills and knowledge to implement the best educational practices. Mizell (2010) argues that professional development is the only strategy through which school systems have to strengthen educators' performance levels. In addition, it is the only way teachers can learn to be able to improve their performance and raise students' achievement. Moreover, Harris, Busher, and Wise (2001) believe that supervisors should be also exposed to professional development since they have a direct impact on teachers, students, and curriculum.

\section{Research setting}

The Lebanese educational system is considered as a free education system and is divided in two sectors: private schools and universities, for which there is a charge for admission, and public (government) schools and universities that are practically free of charge. This system is well developed and reaches all levels of the population. The English language curriculum, implemented since 1997, is based on modern theories of curriculum design and teaching 
methods. This new national curriculum is mainly mandatory for the public sector and optional for private schools. It involves a multiplicity of interrelated learner, teacher, subject, and contextual factors (BouJaoude \& Ghaith 2006). However, this curriculum is quite challenging for those who have been following traditional methods. Many teachers find it often difficult to adapt to a system in which new methodology and time constraints need to be constantly addressed throughout the regular teaching/learning process (Basha \& Bahous, 2011). The methods of instruction used in Lebanese classrooms are mostly traditional. Implementation of new ideas and methods has been hampered by the lack of adequate educational facilities and well-trained professionals in that regard.

However, private schools practice more progressive and advanced methods of instruction, which are geared toward the increasing involvement of students in the instructional process (Education state university, n.d.). Private schools offer specific programs for low achievers as remedial and leveling up to reach mainstream education.

This research took place in a school planning to restart an EIP (English Intensive Program) department for ELLs (English second language learners with a limited or non-English background). Students are identified as English Language Learners (ELLs) and qualify for services when two conditions are met: first, there must be an influence of a language other than English, and second, students must be below grade-level in reading, writing, listening and speaking academic English as measured by a variety of national examinations and other formal assessments. Upon reaching a grade-level fluency of academic English, students are no longer eligible for ELL services, and are exited from the program back to the regular classes.

\section{The problem}

This study is conducted in a private school in Mount Lebanon, where students come from diverse backgrounds. It is an accredited school that follows the new Lebanese curriculum. The school has several programs other than Lebanese such as SED (Special Education Department) for students with learning difficulties, and IB (International Baccalaureate). Although the school encourages cooperative learning and professional development through yearly workshops for all staff, and is always recording $100 \%$ success in the Lebanese Official exams, English language teachers complain about struggling with low performing students in ESL. Moreover, the increase of immigrant students caused more challenges to meet the learning needs of the diverse student backgrounds.

ELLs students at the school face many difficulties in learning English as a second language. They face writing difficulties in expressing themselves and in using the appropriate vocabulary. Also, reading is a frustrating experience for them due to unfamiliar vocabulary, comprehension difficulties, polysemous words which are words with multiple meanings, advanced cohesion, and complex syntax. These students showed to have gaps in language and are below grade-level in reading, writing, listening and speaking, and are now suffering in classes and are unable to catch up with others or to reach the level of their class.

Teachers are not well trained and equipped to teach (ELLs), which keeps students performing below academic expectations. According to the related literature, professional development is the only strategy school systems have to strengthen educators' performance levels. Thus, the absence of well-trained teachers and a well- designed program reveal a great problem. This situation has led the researchers' inquiry into improving instruction for ELLs, and to focus on the following problem questions: 
What are the most prevalent ESL instructional practices that teachers use to instruct their ELL students?

What difficulties teachers face with ELL students when implementing those startegies?

\section{Theoretical perspective}

The U.S. Department of Education (2002) defined ELLs as students "whose language is a language other than English and whose difficulties in speaking, reading, writing or understanding the English language may deny the individual the opportunity to participate fully in society".

Kushner \& Ortiz (2000) pointed out that ELL students are usually transferred to English as a Second Language (ESL) services based on their ability to perform ordinary classroom work. ELL classrooms are typically pull-out programs where students receive support to develop conversational English skills. Students who are "pulled out" of mainstream classes, according to their English-proficiency level, are supplied with once per day support from thirty minutes to an hour. Students in these classrooms generally represent a variety of language groups, and instruction is in English. Cloud (1990) adds that common ELL curriculum models include developmental, content-based, cognitive strategies, life skills, and career-based skills. Heisey \& Robinette (2002), Ortiz \& Kushner (1997) assured that the goal of ELL, a process which takes approximately two years, is to return students to the mainstream classroom on a full-time basis as soon as they become proficient. ELL exit requirements vary, but generally include tests measuring English proficiency. A push-in approach to ELL often occurs during content instruction such as math, science and social studies as mentioned by Obiakor, Bakken \& Rotatori (2010), where the teacher comes into the classroom to attend the needs of an ELL in collaboration with the classroom teacher. However, many ESL teachers have no formal training to teach these subjects as Zacarian (2011) states.

Effective classrooms for ELLs must be customized learning environments that reflect school and community factors and goals, and identify conditions under which specific methodologies are best suited. The curriculum must be flexible in its ability to respond to students' individual needs in terms of skills, knowledge, degree of difficulty, and instructional approaches. Thus, the needs of newcomers and immigrants are anticipated and planned for, to ensure their smooth integration into the classroom.

Hence, effective ELL instruction involves a balanced curriculum that incorporates both basic and higher-order skills, explicit skills instruction to help students acquire basic skills, opportunities for student-directed activities, use of instructional strategies that enhance understanding, use of native language and culture, and other opportunities for practice. Suggested practice opportunities include building redundancy into activities, having ELLs interact with fluent peers, using extended dialogue to enhance English acquisition and learning, and using instructional conversations, or discussion-based lessons that focus on an idea or concept that has educational value, meaning, and relevance for students. In addition, Gersten \& Baker (2000) stated that a good English language development program should focus on developing proficiency and fluency in English by addressing the formal, grammatical aspects of English use and by presenting new academic content. Effective activities may include the use of TPR (Total Physical Response), cooperative learning, language experience approach, dialogue journals, academic language scaffolding, native language support, accessing prior knowledge, and cultural studies. 
Total Physical Response or TPR is a systematized approach where students respond to commands followed by physical responses or actions. It was developed by the psychologist James Asher (1979). It is often used to introduce students to a foreign language and can be used with kindergarten through adult students. It increases the listening skills and helps the beginning student to respond through in a nonthreatening, low-anxiety, whole body way. Commands may involve the entire body, large motor skills, or interaction with concrete materials and manipulatives beginning with classroom objects. Usually ESL classes begin with five to ten minutes with such activities.

Another approach that is also suggested for ELLs is the natural approach. The Natural Approach, developed by Krashen and Terrell (1983), is designed to develop basic communication skill following the developmental stages of: comprehension (pre-production), early production, and speech emergence. This approach to teaching language has been proven to be particularly effective with limited English proficient students.

In order to maximize opportunities for comprehension experiences, natural approach instructors create activities designed to teach students to recognize the meaning of words used in meaningful contexts, and teach students to deduce the meaning of phrases without knowing all of the words and structures of the sentences. As for speech, teachers must not force production of words and must encourage small tries. In speech emergence stage, speech production will normally improve in both quantity and quality. The sentences the students produce become longer and more complex. Students will be able to use a wider range of vocabulary. Finally, the number or errors will slowly decrease. Students need to be given the opportunity to use oral and written language whenever possible including games and recreational activities, problem solving activities using charts, tables, graphs, maps, advertisements and signs. Also group discussions are very important to enhance their oral language.

In general, during early stages of English second language acquisition, ELLs rely heavily on receptive strategies, like repetition and memorization, as they learn words and phrases. During middle stages, ELLs begin to use more interactive strategies, such as verbal attention-getters and elaboration, to engage in and sustain interactions with others. During more advanced stages, ELLs use language and communication monitoring strategies, such as requesting clarification and appealing for assistance, to maintain and, as needed, repair communication with speakers. In their study, O’Malley, Chamot, Stewner-Manzanares, Russo, \& Kupper (1990), suggest that explicit instruction on how to use strategies effectively, especially metacognitive strategies, might be beneficial for ELLs.

\section{The grammar translation method}

The grammar translation method is a third teaching method that has been frequently associated with ESL teaching.

The grammar-translation method approached language learning through a detailed analysis of the language's grammar rules, and then applying the knowledge of the grammar rules to translating sentences to and from the target language as Ibid (2001) has mentioned. Because of this, the student's first language has importance to and is involved in the language learning process.

Aslam (2003) states that the first language is the basis for acquiring the second language. Richards \& Rodgers, (2001) add that the first language is also used as the medium of instruction to explain new items. 
CLT - Communicative Language Teaching Approach This method requires activities that enhance meaningful communication among language learners according to Richards (2006). Richards (2006) summarizes the CLT principles as follows: make real communication the focus of language learning, provide opportunities for learners to experiment and try out what they know, be tolerant of learners' errors as they indicate that the learner is building up his or her communicative competence, provide opportunities for learners to develop both accuracy and fluency, link the different skills such as speaking, reading, and listening together, since they usually occur so in the real world, and let students discover grammar rules.

\section{Evaluation of ELLS}

Ells are evaluated on skill growth in many ways. Evaluation instruments include both summative and formative assessments. Summative assessment includes a summary of assessments of students' performances including testing and examinations. It gives a general overview about the students' performance throughout the level, and it is referred to mainly with ELLs to decide upon promotion, certification, admission to higher levels, or mainstreaming. Formative assessment consists of the information gathered in the assessment process to identify learning needs. Formative assessment methods produce significant learning gains as assured by OECD (2011). It encompasses classroom interactions, questioning, structured classroom activities, and feedback aimed at helping students to close learning gaps. It is important to identify ELLs' areas of improvement in the level. Moreover, diagnostic assessment is also used, prior to instruction, to check each student's level, weaknesses, and strengths allowing the instructor to remediate students and adjust the curriculum to meet each student's unique needs. Evaluation instruments may also include formal and informal assessments. Formal assessment measures can include language proficiency tests, achievement measures in the content areas, and unit tests. Informal, or alternative assessments, can include teacher observations, holistic ratings of student writing, student journals, or self-ratings. Portfolio assessment is also recommended as an authentic assessment tool to monitor students' growth.

The purpose of assessment is to indicate students' level, to make instructional decisions, and to check program development. According to Hurley and Blake (2000), the holistic context of learning should be considered and assessed. Moreover, the best assessment practices for students' learning are longitudinal taking place over time.

\section{English as a Foreign Language Education in Lebanon}

As an important tool for communication, interest has increased to reveal the concerns, problems and needs of Arab learners studying English as a second language. In the conference organized by the Arab Open University in Lebanon, on Multiple Perceptual Frames on English Language Teaching and Research, co-sponsored by the British Council, on 22-23 March, 2011, it was concluded that traditional approaches to English Language teaching have not resulted in sufficient preparation for the learner.

Cummins (2000) propose the interval of "at least 5 years of continued practice" to achieve a good level of appropriate academic proficiency in the second language. This includes writing skills, reading comprehension, knowledge of a range of vocabulary items including specific lexis and technical terms, and a developed syntactic repertoire.

It is noticeable that the pressure to teach English as a foreign language from early age is more advanced in Lebanon than in other Arab countries. Research in the Lebanese context revealed the low status of the profession, the female majority among teachers, due to the increase of privatization as well as the poor perception many teachers have of the usefulness of most 
training, whether pre- or in-service. Moreover, Lebanon is facing a difficulty in producing thoughtful teachers proficient in English. Orr (2011) indicated in his study that teachers need to develop critical reflective skills. Masri (2009) discusses this phenomenon, evident in the increase in private universities too in Lebanon from 19 in the 1990's indicated by BouJaoude (2000) to nearly 40 in the following decade (Lebanese Association for Educational Studies, n.d.). English is the medium of instruction, while Arabic is restricted to a few humanities subjects. However, despite studying and being taught in English for up to twelve years at school, many students have to take remedial English language courses as a condition of entry to university as assured by Nasser and Goff-Kfouri (2008). Also, research done by a team from Arab open university in Lebanon, headed by Al Khatib, revealed that the Arabic language background learners studying English as a second language face many difficulties. Phonological difficulties involved vowel phonemes, appropriate segmentation, prosodic features of stress and intonation at beginners' levels. Lexical difficulties that relate to essential vocabulary, and the use of inappropriate extension of a word, substitution or replacement, also identified the performance of learners at beginners' level. Grammatical difficulties included: articles and determiners, prepositions, count and non-count words, auxiliaries and modal verbs as well as syntax errors. Cognitive difficulties were revealed related to improper idiomatic usage and phrasal verbs.

On the other hand, some factors were found to contribute to successful second language acquisition. Comprehensible input, contextualized learning, negotiated interaction, feedback, and tutor's guidance and encouragement have shown a great influence in learning English as a second language. More immersion in the English language was recommended, through offering varied resources, example reading club, language lab, and group discussion which would expand the lexical resources of the learner, and provide opportunities for listening comprehension, vocabulary building and conversational skills.

Furthermore, recommendations were offered that included the avoidance of teaching grammar rules and vocabulary lists, and the avoidance of outdated traditional language teaching techniques. However, the learner must be given opportunities to use the second language for communicative purposes taking into consideration the aim of keeping the learner motivated and encouraged too. Moreover, the research team recommended conducting a campaign to raise awareness for parents and students on the importance of English in gaining access to employment. Active commitment to learning the global language can bring better effort and performance, on the part of the learners and more support on the part or parents of families, and may result in the expansion of the context of use.

In fact, the importance to change lessons from traditional styles such as a translation basedinstruction or a grammar-based instruction to a communicative approach has been advocated for years in the new Lebanese curriculum. Consequently, many teachers are looking at how to shift their lessons to meet new education purposes. Some may have successfully changed their teaching styles. However, lessons are still more teacher centered than student-centered in some classrooms. In addition, lessons are designed to include whole class activities such as lectures instead of pair work or group work. This approach, however, is not good for increasing students' interaction in order to acquire communicative skills or even for keeping students' attention.

\section{RESEARCH METHODOLOGY}

The current study is a case study. A case study is a contemporary phenomenon, as defined by Merriam (2009) \& Stake (1995), which cannot be separated from its context. In this case, separating the context of the EIP classroom from the phenomenon of exploring the experiences 
of the teachers and involvement of students was impossible. Case studies, as Stake (1995) stated, are good for describing and expanding the understanding of a phenomenon and are often used to study people and programs particularly in education. As opposed to other forms of research, case study places the researcher into the field in order to observe and record, "objectively what is happening but simultaneously examines its meaning and redirects observations to refine or substantiate those meanings" (Stakes, 1995, p. 9). In order to maximize learning and "preserve multiple realities" (Stake, 1995, p. 12), participants will be selected based on their unique perspective. In order to get a sampling of several caring teachers, 25 participated; while allowing for an in-depth study of each one, 3 teachers were asked to participate. The teachers were selected based on several criteria such as willingness, experience with ELLs, and university degrees.

Another element of this research, which met the criteria of a case study, as stated by Yin (2008), Merriam (2009) \& Stake (1995), is the bounded system of the EIP classrooms. The boundaries of the case were clear. The class is an English Intensive program class, taught by an EIP teacher who has had no previous training. This case study strove to meet Merriam's (2009) three standards for a case study by being (1) particularistic because it focuses on the particular situation of the EIP classroom and focused on the experiences of the teachers and ELLs who were in this EIP classroom; (2) descriptive because the resulting product of this case study was a rich, complete, multi layered descriptive presentation of the experiences of the informants from this EIP classroom; and finally, (3) heuristic because it sought to enhance the field's understanding of the educational experiences involved with including ELLs in the EIP classroom. Considering the resulting research questions, multi-case study design is the most appropriate choice for me to conduct this study from the point of improvement of Ells' writing skills.

In this study, 2 students from two different upper elementary levels constituted the multi-case study, but the implementation took place inside the classroom. First student was from level 5 and the second from level 6. They cannot be pulled out of their EIP classroom since this class is the main concern of the study where the intervention program would be implemented. The whole context must be under study such as teacher's strategies, resources, school's and supervisor's encouragement to this program, and students' motivation and engagement. The study is also concerned with the students work (writing samples) before and after implementation and throughout the lessons.

According to the boundaries of the case study, the researcher gave detailed description of the case:

The EIP department consists of three classes and three teachers. A suitable friendly and lovely educational environment that fosters cooperative work is provided for E.I.P. students.

E.I.P. 1 class caters for grade 1 and 3 English levels as per School standards.

E.I.P. 2 caters for grades $5 \& 6$ English levels as per school standards.

E.I.P. 3 caters for grades 8 \& 10 English levels as per school standards.

\section{RESEARCH INSTRUMENTS}

\section{Questionnaire}

A questionnaire was used pre-implementation of the intervention plan for all population represented by all English teachers in the English department (25 teachers) to collect data that determines the level of use of ESL strategies and research-based practices in the instruction of ELL students in the classrooms. Moreover, this questionnaire helped determine the needs of teachers to take them into consideration in preparing the professional development plan. 
The questionnaire was given to teachers after the principal's and the teachers' consent. The main focus and objective of the survey was to analyze and establish what research based ESL instructional practices were to instruct ELL students.

The use of a quantitative approach requires a course of action that includes collecting, analyzing, interpreting, and recording the outcomes of the study conducted (Creswell, 2014). The study used descriptive statistics in order to focus on the level of preparedness of educators in the areas of ESL strategies and the inclusion of ESL research-based practices.

The survey instrument was developed using a framework based on published research on proven practices identified and delineated in the literature review. The survey consisted of 41 questions and encompassed 5 dimensions: (a) instructional practices, (b) ESL strategies, (c) principles for building English language learners responsive learning environments, (d) staff development, and (e) instructional strategies.

The questionnaire used was adapted from several studies in this field. It consists of 4 dimensions.

Dimension 1 questions were based on classroom instructional practices outlined in Classroom Instruction that Works (Marzano, Pickering, \& Pollock 2001), and the findings of National Reading Panel and National Council for Teachers of English (NCTE) Standards.

Dimension 2 questions were based on Effective Teaching Practices for English Language Learners: Spotlight on Student Success, (Waxman \& Tellez, 2002).

Dimension 3 questions were based on principles outlined in Claiming Opportunities: $A$ Handbook for Improving Education for English Language Learners through Comprehensive School Reform.

Dimension 4 questions were based on National Staff Development Council Standards for Staff Development.

Dimension 5 questions were based on instructional practices outlined in Educating English Language Learners: Implementing Instructional Practices by NCLR (National Council of La Raza) and Education Alliance at Brown University (Vialpando et al, 2005).

The instrument was constructed on a Likert scale with five possible answers to each questionnaire statement (Strongly Agree, Agree, Neutral, Disagree, and Strongly Disagree), and it was validated by a panel of experts before it was used in order to ensure construct and content validity and to make recommendations for improvement. The survey was based on several frameworks developed by researchers and recognized educational organizations in the field of language acquisition that include research-based practices proven to be effective in the field of ESL and a standards-based school reform environment. This tool was distributed to teachers after the English departmental meeting and after receiving the voluntary agreement of all teachers to participate in the study.

\section{Semi- structured interview}

A semi-structured interview was conducted with teachers to measure teachers' challenges with ELLs and take further suggestions. This interview consists of three fields. The first, students' field, consists of 3 open-ended questions. The second, teachers' field, consists of 6 open-ended questions. The third field, the supervisor's field consists of five closed-ended questions with two options of answering by choosing either yes or no. 


\section{Secondary data Collection tools:}

1- Tables for students' work. The content analysis tables include two fields: five points constituting students' types of mistakes, and four other points constituting teachers' actions.

The purpose of this tool is to check students' achievement and teachers' encouragement and strategies used. Content analysis of students' work took place at the supervisor's office after collecting writing samples done by students before and after implementation of the intervention program. This tool was mainly constructed by the researcher based on the content being presented in the literature review relating to teachers' encouragement and correction and Ells' challenges in writing. However, this tool has been validated by a member of the OECD, an English language teacher, and slight modifications were added.

2- Observation guides measuring ESL strategies, effectiveness of writing activities, ELL s' motivation, and reflection practices. A meeting took place before each observation with the teacher of upper elementary levels $(5 \& 6)$ to discuss the tool used and another meeting after observation conducted took place to provide feedback. Four free observations took place. The free observation guide checks classroom environment and communication skills of teacher.

Triangulation was achieved through the collection of multiple sources of data, to further enhance internal validity. Patton (2001) advocates the use of triangulation by stating "triangulation strengthens a study by combining methods. This means using several kinds of methods or data, including both quantitative and qualitative approaches" (p. 247). Moreover, all the tools were validated by supervisors.

\section{Results}

\section{Questionnaire results:}

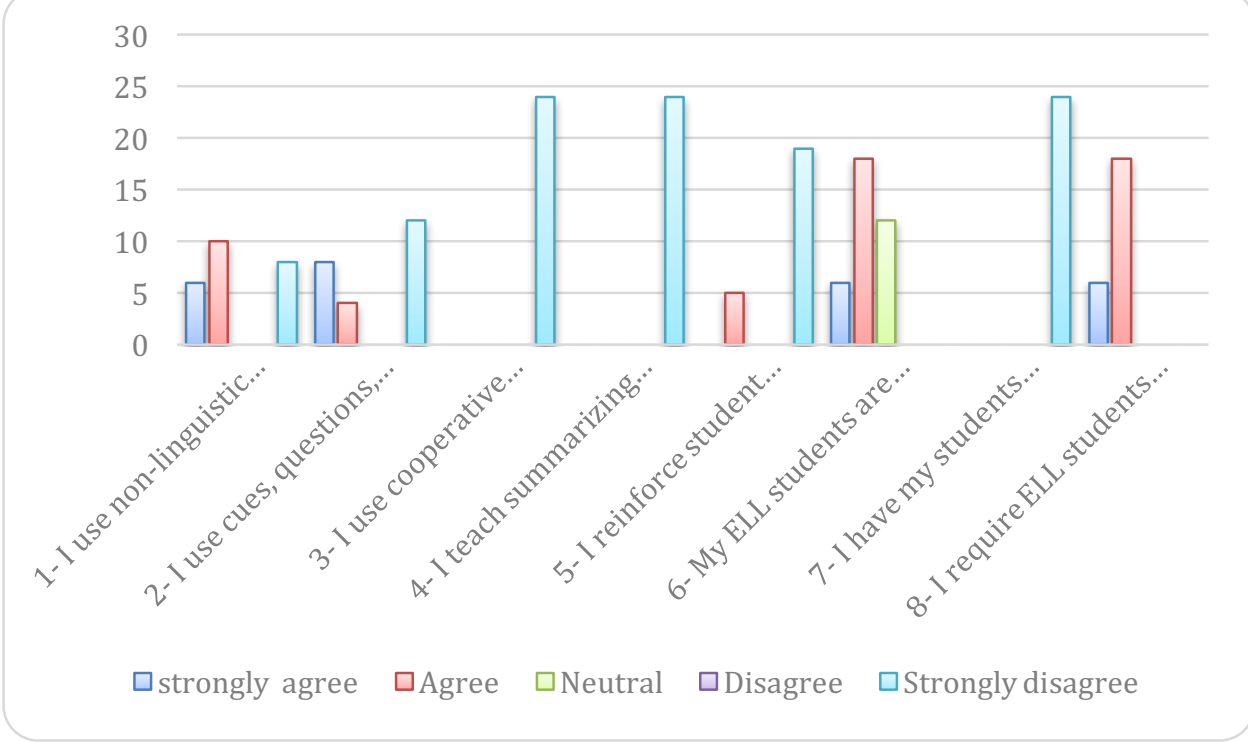



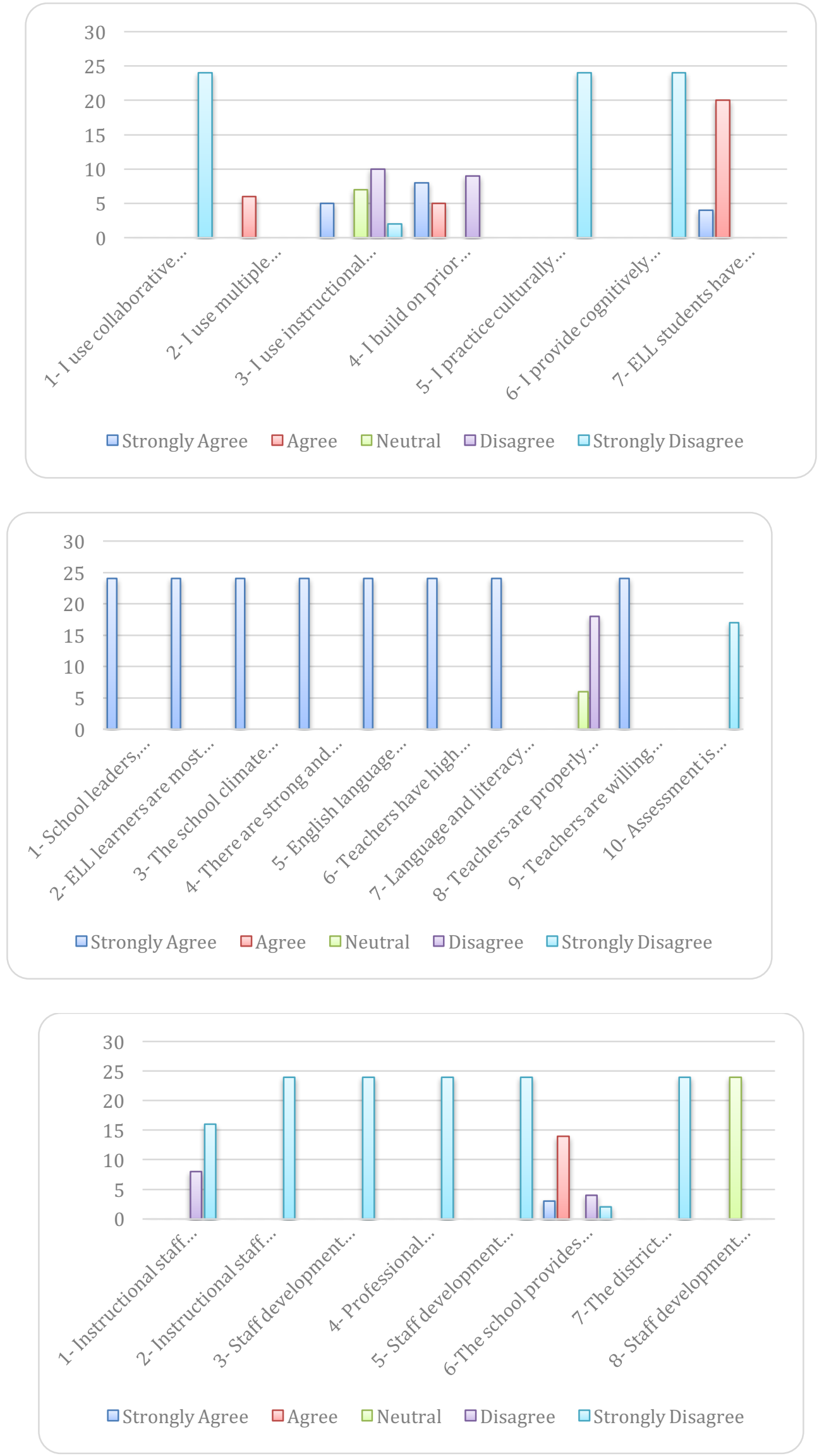


\section{Barriers to Meaningful Instruction for ELLS}

There are four loads that can be identified as barriers to meaningful instruction; cognitive load, culture load, language load and learning load. It is demanded that the English language teachers must be skilled enough at lowering these barriers and sparking student interest and curiosity by developing a creative, wise and passionate curriculum. 


\begin{tabular}{|c|c|}
\hline \multicolumn{2}{|c|}{ Cognitive Load } \\
\hline number of new concepts embedded in a lesson: & $\begin{array}{l}\text { Teachers do not assess prior knowledge of students to } \\
\text { identify the concepts and skills they do and do not } \\
\text { possess }\end{array}$ \\
\hline & $\begin{array}{l}\text { The teacher did not ask questions to check pre- } \\
\text { requisites or to build on prior knowledge material. }\end{array}$ \\
\hline \multirow[t]{5}{*}{ conceptual gaps: } & $\begin{array}{l}\text { Teachers do not by try to relate new concepts to life } \\
\text { experiences of ESL students }\end{array}$ \\
\hline & $\begin{array}{l}\text { The classroom is not conductive for freedom of } \\
\text { expression }\end{array}$ \\
\hline & Teachers did not relate new information to old \\
\hline & $\begin{array}{l}\text { Teacher did not adapt her instruction to meet students' } \\
\text { levels }\end{array}$ \\
\hline & $\begin{array}{l}\text { Teacher assigns a "helpmate" for students who need } \\
\text { extra help }\end{array}$ \\
\hline \multicolumn{2}{|l|}{ Culture Load } \\
\hline \multirow[t]{2}{*}{$\begin{array}{l}\text { the amount of cultural knowledge required to } \\
\text { comprehend meaning or participate in an activity: }\end{array}$} & $\begin{array}{l}\text { Meanings of words are not determined by the uses } \\
\text { of words within linguistic and cultural settings. } \\
\text { Teachers exposed students difficulty in "finding the } \\
\text { suitable vocabulary words" }\end{array}$ \\
\hline & $\begin{array}{l}\text { The teacher prepares a mini library in class with } \\
\text { dictionaries according to students' mother language }\end{array}$ \\
\hline $\begin{array}{l}\text { how teachers expect interaction to occur in a } \\
\text { classroom that includes when to speak, when to } \\
\text { stay silent, when to respond and when to write: }\end{array}$ & $\begin{array}{l}\text { they use visual props, gestures, and facial expressions } \\
\text { to communicate with their students }\end{array}$ \\
\hline $\begin{array}{l}\text { Teachers should treat English learners with } \\
\text { respect and lack of judgment, and they should try } \\
\text { to be friendly with students: }\end{array}$ & $\begin{array}{l}\text { motivate their students using verbal recognition } \\
\text { The teachers do not label everything in the room to } \\
\text { help student feel at home } \\
\text { they don't ask their students to provide feedback for } \\
\text { students' improvement in writing }\end{array}$ \\
\hline \multicolumn{2}{|l|}{ Language Load } \\
\hline \multirow[t]{7}{*}{ number of unfamiliar words encountered: } & Teachers did not rewrite or explain text material \\
\hline & $\begin{array}{l}\text { Complex sentences were not broken down into } \\
\text { comprehensible parts }\end{array}$ \\
\hline & Teacher doesn't deduct grades on spelling mistakes \\
\hline & $\begin{array}{l}\text { Teachers did not prepare checklists to help students } \\
\text { revise their work }\end{array}$ \\
\hline & $\begin{array}{l}\text { Teacher do not encourage students to categorize, and } \\
\text { use a dictionary }\end{array}$ \\
\hline & $\begin{array}{l}\text { The teacher does not involve all students in different } \\
\text { skills }\end{array}$ \\
\hline & Teacher includes different activities \\
\hline \multicolumn{2}{|l|}{ Learning Load } \\
\hline $\begin{array}{l}\text { It represents what teachers expect students to do } \\
\text { with English in the learning activities }\end{array}$ & $\begin{array}{l}\text { "using the appropriate strategies in reaching students" } \\
\text { gaps in writing" }\end{array}$ \\
\hline \multirow{6}{*}{$\begin{array}{l}\text { making adaptations and offering supports } \\
\text { accordingly }\end{array}$} & "motivating students" \\
\hline & assessing students' improvement \\
\hline & $\begin{array}{l}\text { Teachers do not integrate activities that suit different } \\
\text { students' learning styles taking into consideration } \\
\text { students who receive information better in reading, } \\
\text { list ening, drawing, or experiencing }\end{array}$ \\
\hline & $\begin{array}{l}\text { They don't provide feedback for students' } \\
\text { improvement in writing after each stage. }\end{array}$ \\
\hline & The student do not solve problems in groups \\
\hline & $\begin{array}{l}\text { The teacher does not include active learning } \\
\text { strategies such as group work, role play, competitions. }\end{array}$ \\
\hline
\end{tabular}




\section{Content Analysis:}

\begin{tabular}{|c|l|l|l|l|l|l|l|l|l|}
\hline & \multicolumn{5}{|c|}{ Students' Mistakes } & \multicolumn{3}{c|}{ Teachers' Actions } \\
\hline & $\begin{array}{c}\text { Spelling } \\
\text { mistakes }\end{array}$ & $\begin{array}{c}\text { Use of } \\
\text { words in } \\
\text { native } \\
\text { language }\end{array}$ & $\begin{array}{c}\text { Empty } \\
\text { spaces }\end{array}$ & $\begin{array}{c}\text { Short } \\
\text { sentences }\end{array}$ & $\begin{array}{c}\text { Sentence } \\
\text { structure } \\
\text { problem }\end{array}$ & $\begin{array}{c}\text { Teacher's } \\
\text { correction }\end{array}$ & $\begin{array}{c}\text { Teacher's } \\
\text { notes }\end{array}$ & $\begin{array}{c}\text { Positive } \\
\text { recognition }\end{array}$ & $\begin{array}{c}\text { Negative } \\
\text { recognition }\end{array}$ \\
\hline $\begin{array}{c}\text { Student } \\
\text { A 1 }\end{array}$ & + & & + & + & + & + & & & \\
\hline $\begin{array}{c}\text { Student } \\
\text { A 2 }\end{array}$ & + & & + & + & + & + & & & \\
\hline $\begin{array}{c}\text { Student } \\
\text { B 1 }\end{array}$ & + & & & + & + & + & & & \\
\hline $\begin{array}{c}\text { Student } \\
\text { B 2 }\end{array}$ & + & & & + & + & + & & & \\
\hline
\end{tabular}

\section{DISCUSSION OF RESULTS}

The results of data collection through interviews, class observations, and questionnaires showed that the difficulties that teachers face with ELLs are a result of lack of training. The preintervention stage revealed clearly that teachers didn't know how to customize the learning environments under which specific methodologies are best suited. One Teacher answered that one of the challenges that she faces with ELLs is "using the appropriate strategies in reaching students gaps in writing". 75\% of the teachers weren't well prepared to teach ELLs as discovered in the questionnaires distributed. Another teacher found difficulty in motivating ELLs and another teacher in "assessing students' improvement". Reflection strategies were absent, and teachers' encouragement depended highly on verbal recognition. Thus, many ESL teachers have no formal training to teach these subjects as Zacarian (2011) states.

ELLs face many difficulties in learning English as a second language. They face writing difficulties in expressing themselves and in using the appropriate vocabulary. Also, reading is a frustrating experience for them due to unfamiliar vocabulary, comprehension difficulties, polysemous words which are words with multiple meanings, advanced cohesion, and complex syntax. In this study, ELLs have been frustrated in the pre-implementation stage, which was clear in their writing samples that included many empty spaces in the pre-intervention stage. Moreover, coming from a non-English background (Russia and Argentina), students have shown to have many spelling mistakes in their writings. They used short sentences and faced difficulties in sentence structure. However, it was an effective experience for them where $100 \%$ of the students in the post implementation stage answered that they like the English language. They also agreed that learning English is interesting. Also, their writing samples improved to lack now empty spaces. As for the interviews conducted in the pre-intervention stage, they clearly show the difficulty that teachers and ELLs face through mentioning that "Ells' grades in English writing are below the class average" as all teachers agreed. Moreover, two teachers stated in the interview that the academic problems that ELLs face in writing are "spelling problems" and another teacher said "finding the suitable vocabulary words". Furthermore, the interviews pinpointed the challenges ELL teachers face in teaching writing where one teacher answered "using the appropriate strategies in reaching students' gaps in writing", another teacher answered "motivating students", and the third teacher answered "assessing students' improvement". This study encouraged students to use dictionaries related to their native language, and this has shown a great effect in improving their writing and replacing the empty spaces in their writing by words familiar to them in their native language. Thus, this decreased students' frustration and helped them express themselves freely. 


\begin{tabular}{|l|l|}
\hline Difficulty Observed in the Student & Observed teacher practice \\
\hline Difficulty in reading and spelling words & $\begin{array}{l}\text { Lack of exposure to English word reading and spelling; } \\
\text { unfamiliarity with English words }\end{array}$ \\
\hline $\begin{array}{l}\text { Difficulty in comprehending text; Knowledge of } \\
\text { English language skills (sentence structure, } \\
\text { vocabulary, grammar, morphology, pragmatics) } \\
\text { underdeveloped; }\end{array}$ & $\begin{array}{l}\text { lack of relevant background knowledge Language } \\
\text { processing problems }\end{array}$ \\
\hline Poor writing skills & $\begin{array}{l}\text { student does not have the language skills to express } \\
\text { thinking }\end{array}$ \\
\hline Easily distracted students & $\begin{array}{l}\text { Doesn't understand; requires more visual/concrete } \\
\text { support; is overwhelmed \& exhausted by language } \\
\text { learning process }\end{array}$ \\
\hline Trouble following directions & Doesn't know the vocabulary used \\
\hline Problem in remembering information taught & $\begin{array}{l}\text { Students are overwhelmed with multiple demands of } \\
\text { language learning }\end{array}$ \\
\hline
\end{tabular}

\section{Instructional Strategies}

Research about instructional strategies showed the importance of providing students with challenging activities but at the same time built on prior knowledge in order to ensure that the activity is comprehensible and at the students' level of proficiency. In addition, it focuses on providing opportunities for interaction on a consistent basis must be provided in real and authentic situations and non-frustrating environment to promote language learning. One teacher stated that "finding the suitable instructional strategies" was a challenge for her especially to reach students' writing gaps. English language teachers find it very challenging to reach ELLs and to find suitable strategies that cater for diverse situations.

Furthermore, sheltered instruction (SI) that include speaking at a rate and level of complexity appropriate to the proficiency level of the students, using visual aids and manipulatives, building on students' prior knowledge, providing frequent opportunities for students to interact, modeling academic tasks, and reviewing key-content concepts and vocabulary are considered among other essential features. Hence a focus is needed on differentiated ELL instruction because diverse students have different needs and interests that should be considered. Also, the literature reveals that real communication in a non-frustrating environment and the use of the first language is the basis for promoting language learning.

All teachers revealed that they didn't give attention to implementing activities that suit different learning styles. Thus, it is clear that teachers didn't use differentiated instruction in their teaching practices. However, all EIP teachers used visual props, gestures, and facial expressions to communicate with their students. As for English teachers who constitute the whole population, only 33\% of them used visual aids. Also, teachers didn't check pre-requisites to build on prior knowledge. 33\% of all English teachers build on prior knowledge. Teachers didn't encourage students in the pre-implementation stage to use a dictionary of the students' native language and to work collaboratively. In addition, teachers didn't implement previously cultural-based activities. However, communication in class and discussion strategies were implemented effectively.

\section{School \& classroom effectiveness}

The literature of this study showed clearly school- or classroom-level factors that include a supportive school environment where value is placed on the linguistic and cultural background of ELLs. It also included that ELLs must be integrally involved in the overall school operation, and teachers should be trained to acquire the skills and knowledge needed to be successful with them. In addition, the principal must include ELLs in the planning, coordinating, and administering programs, providing ongoing direction and monitoring of curricular and 
instructional improvement and preparing dedicated staff. Besides, the principal must involve the entire staff in improvement efforts and provide a good physical and social environment.

All teachers agreed that the school leaders, administrators, and educators recognize that educating ELLs is the responsibility of the whole school. Also, that school climate reinforces the idea that different cultures are resources for learning. Ells also have equitable access to school resources and programs. Teachers have high expectations of ELLs and are willing to teach students. Furthermore, classrooms were designed to comfort students and reach all their interests and needs equipped with the latest technology and needed resources such as a minilibrary, computer, earphones, internet connection, active board, language lab...Also, students' projects are always displayedon bulletin boards inside the classroom. ELLs are highly appreciated at school and cultural-based activities started taking place on a weekly basis after the intervention plan.

\section{Customized Learning environments}

Effective classrooms for ELLs must be customized learning environments that reflect school and community factors and goals, and identify conditions under which specific methodologies are best suited. The curriculum must be flexible in its ability to respond to students' individual needs in terms of skills, knowledge, degree of difficulty, and instructional approaches as the literature stated. Thus, the needs of newcomers and immigrants are anticipated and planned for, to ensure their smooth integration into the classroom. This includes student-directed activities that are modified to meet students' needs. These strategies include: speaking at a rate and level of complexity appropriate to the proficiency level of the students, using visual aids and manipulatives, building on students' prior knowledge, providing frequent opportunities for students to interact, modeling academic tasks, and reviewing key-content concepts and vocabulary among other essential features. Customized learning environments point out to the use of differentiated ELL instruction because diverse students have different needs and interests that should be considered. Moreover, this demands from the teachers some efforts in providing students with challenging activities but at the same time built on prior knowledge in order to ensure that the activity is comprehensible and at their level of proficiency.

\section{Motivation is one aspect of customized learning environment observed through the tools.}

According to the literature, there are outside factors that affect a person's motivation when learning a second language such as the teacher's attitude and the classroom environment. Also, verbal and nonverbal interventions in class play a core role in motivating students. The literature also reveals that motivating unmotivated children demands providing choice to students, providing feedback, and helping the students feel competent by providing high expectations. Moreover, considering the learning styles of ELLs may contribute to successful language learning and may result in individual student successes.

Teachers stated in the interviews that they only used verbal recognition only to motivate their students. Moreover, teachers didn't give attention to implementing learning styles. However, integrating learners' first language and cultural aspects in content that goes along with communicative learning, after intervention, raised ELL's motivation and provided higher opportunities for greater improvement in their writing skills.

\section{Reflection is one aspect of customized learning environment observed throughout the tools:}

The literature discussed the importance of the reflection process where an individual critically examines practice. It also reflects the effective results of reflection on turning experiences into 
meaningful learning. Teachers stated that they didn't provide feedback for students and didn't give students the chance to reflect upon their learning.

\section{References}

Asher, J. (1981). The total physical response: theory and practice. Native Language and Foreign Language Acquisition, 379, 324-331.

Aslam,M. (2003). Teaching of English. New Delhi: Foundation Book.

Awada, G. \& Diab, H. (2016). Lebanon's 2011 ICT education reform strategy and action plan: Curriculum success or abeyance. Cogent Education, 3: 1245086. http://dx.doi.org/10.1080/2331186X.2016.1245086.

Basha, N.\& Bahous, R. (November, 2011). "Foreign Language Education in Lebanon: A Context of Cultural and Curricular Complexities" . Journal of language teaching and research, 2 (6), 1320-1328,.Academy Publisher. Doi: 10.4304 /jltr. 2.6.1320-1328.

BouJaoude, S., \& G. Ghaith (2006). Educational reform at a time of change: the case of Lebanon. In J. Earnest \& D. Tragust (eds.) Education reconstruction in transitional societies. The Netherlands: Sense Publishers, 193 - 210.

BouJaoude, S. (2000). Trends in science teacher preparation. In the Proceedings of the conference on Science Teaching: Content, Pedagogy, and Evaluation (L'enseignemnet des sciences: Contenu, didactique et evaluation) organized by the Center for Educational Research and Development and L'Institut Libanais d'Educateurs de l'Universite Saint Joseph (pp. 24-31). April 17-18, 2000.

Cloud, N. (1990). Planning and Implementing an English as a Second Language Program. In A.L. Carasquillo \& R. E. Baecher (Eds.), Teaching the Bilingual Special Education Student (pp. 106-131). Norwood, NJ: Ablex Publishing Corp.

Creswell, John W. (2014). Research design: Qualitative, quantitative and mixed methods approaches (4th ed.). Thousand Oaks, CA: Sage.

Cummins, J. (2000). Language, Power and Pedgogy: Bilingual Children in the Crossfire. Clevedon: Multilingual Matters.

Gersten, R. \& Baker, S. (2000). What We Know about Effective Instructional Practices for English-Language Learners. Exceptional Children, 4(66), 454- 470.

Ghaith, G., \& Awada, G. (2014).Effective pedagogical and learning approaches and strategies in the acquisition of English language: A descriptive/analytic study of grades 3, 6, and 9 of basic education. Beirut: Center for Educational Research and Development.

Harris, A., Busher, H., Wise, C. (2001). Effective Training for Subject Leaders. Journal of In-Service Education,. 27 (1), 83-93.

Hurley, S.R., \& Blake, S.(2000). Assessment in the content areas for students acquiring English. In S.R. Hurley \& J.V. Tinajero (Eds),Literacy assessment of second language learners (pp.84-103). Boston: Allyn \& Bacon

Krashen, S.D. \& Terrell, T.D. (1983). The natural approach: Language acquisition in the classroom. London: Prentice Hall Europe.

Kushner, M. I., Ex Ortiz, A. A. (2000). The preparation of early child- hood education teachers for English language learners. In New teachers for a new century: The future of early childhood professional development (pp. 124154). Washington, DC: U.S. Department of Education, National Institute on Early Childhood Development and Education.

Marzano, R. J., Pickering, D. J., \& Pollock, J. E. (2001). Classroom instruction that works: Research-based strategies for increasing student achievement. Alexandria, VA: Association of Supervision and Curriculum Development.

Masri, M. (2009). Policy process and education reform in the Arab world. Mediterranean Journal of Educational Studies, 14(1), 129-144.

Merriam, Sharan B. (2009). Qualitative research: A guide to design and implementation (2nd ed.). San Francisco, CA: Jossey-Bass.

Ministry of Education and Higher Education (2011). Achievements 2010. Retrieved online from:

http://www.mehe.gov.lb/uploads/file/Reports/2011/Progress_Report of Ministry_of_Education_18 5_2011_(Re paired).pdf

Mizell, H. (2010). Why professional development matters. Oxford, OH: Learning Forward.

Moreno, R. (2005). Instructional technology: Promise and pitfalls. In L. PytlikZillig, M. 
Bodvarsson, \& R. Bruning (Eds.), Technology-based education: Bringing researchers and practitioners together(pp. 1-19). Greenwich, CT: Information Age Publishing.

Nasser, R \& Goff-Kfouri, CA. (2008). Assessment of the English remedial program at a private university in Lebanon. Mediterranean Journal of Educational Studies. 13:1, 85100.

NCES. (2002). The condition of education. Washington, DC: US Department of education.

OECD. (2015). Pisa results in focus. Retrieved online from: https://www.oecd.org/pisa/pisa-2015-results-infocus.pdf.

O'Malley, J Michael \& Anna Uhl Chamot (1990). Learning strategies in second language acquisition. Cambridge: Cambridge University Press.

Orr, M. (2011). Learning to teach English as a foreign language in Lebanon. Near and Middle eastern Journal of Research in Education, doi: 10.5339/nmejre.2011.2

Richards, J. C. (2006). Communicative Language Teaching Today, New York: Cambridge University Press.

Richards, J.C. and Rogers T.S. (2001). Approaches and Methods in Language Teaching. New York: Cambridge University Press.

Stake, Robert E. (1995). The art of case study research. Thousand Oaks, CA: Sage.

United Nations. (20005). Committee on the rights of the child consideration of reports submitted by states parties under article 44 of the convention. Third periodic reports of States parties due in 2003, LEBANON,

CRC/C/129/Add.7, Retrieved from:

https://unispal.un.org/DPA/DPR/unispal.nsf/1ce874ab1832a53e852570bb006dfaf6/74740ad8ca0939e085257 11d0069c24b?OpenDocument.

Vialpando, J., J. Yedlin, C. Linse, M. Harrington, and G. Cannon. 2005. Educating English Language Learners: Implementing Instructional Practices. Providence, RI: National Council of La Raza and the Education Alliance at Brown University. http://cas.umkc.edu/gkcwp/download/NCLR-Educating-ELL.pdf

Waxman, H.C., \& Téllez, K. (2002). Research synthesis on effective teaching practices for English language learners. Philadelphia, PA: Temple University. (ERIC Document Reproduction Service No. ED 474821)

Zacarian, D. (2011). Making data-driven decisions based on effective measures of English learner performance: How ESAs can provide support. Perspectives, 17, 61-66. 